\title{
11. OXYGEN AND CARBON ISOTOPIC VARIATION IN PLIOCENE BENTHIC FORAMINIFERS OF THE EQUATORIAL ATLANTIC 1
}

\author{
W. B. Curry ${ }^{2}$ and K. G. Miller ${ }^{3}$
}

\begin{abstract}
Large changes in benthic foraminiferal $\delta^{18} \mathrm{O}$ and $\delta^{13} \mathrm{C}$ occurred during the Pliocene (between 3.0 and $2.0 \mathrm{Ma}$ ) at Hole $665 \mathrm{~A}$. Oxygen isotopic compositions increased to maximum values at $2.4 \mathrm{Ma}$, correlating with an ${ }^{18} \mathrm{O}$ enrichment observed at Hole 552A and other locations (Shackleton et al., 1984). As at Hole 606 (Keigwin, 1986), however, maximum $\delta^{18} \mathrm{O}$ values at $2.4 \mathrm{Ma}$ were not as great as at Hole $552 \mathrm{~A}$, and enrichments in $\delta^{18} \mathrm{O}$ also occurred before $2.4 \mathrm{Ma}$. We believe that the section representing sediments from 2.5 to 2.7 or $2.8 \mathrm{Ma}$ is missing at Hole $552 \mathrm{~A}$ because of incomplete core recovery. Consequently, the older $\delta^{18} \mathrm{O}$ increases are not found at Hole 552A.

Benthic foraminiferal $\delta^{13} \mathrm{C}$ values are much lower at Hole 665 A than at Hole 552A, approaching the low values observed in the Pliocene Pacific Ocean. This geographic distribution of $\delta^{13} \mathrm{C}$ suggests that, like late Quaternary glaciations, the equatorial Atlantic Ocean was dominated during the Pliocene by deep water that originated in the Southern Ocean and had chemical characteristics very similar to the Pacific Ocean. Reduced $\mathrm{O}_{2}$ values were probably associated with low $\delta^{13} \mathrm{C}$ values and contributed to increased preservation of organic carbon during enriched ${ }^{18} \mathrm{O}$ intervals of the Pliocene equatorial Atlantic.
\end{abstract}

\section{INTRODUCTION}

Climatic changes accompanying the major phase of Northern Hemisphere ice growth (2.4 Ma) are not yet well known. The purpose of this report is to determine the changes in chemistry that occurred in the deep eastern Atlantic Ocean during the Pliocene spanning this important climatic transition. We infer changes in the ocean's chemistry from variations in sediment chemistry and lithology observed in the eastern Atlantic at Ocean Drilling Program (ODP) Site 665.

Sediments at this location were recovered using the advanced hydraulic piston corer (APC), and they span the last 4.5 m.y.; no evidence for hiatuses was observed within this interval. The site was double cored with an offset so that missing sections caused by coring disturbance could be evaluated. In addition, the paleomagnetic record for this site was excellent, with all of the major magnetochrons represented back to at least the Gauss.

We will interpret changes in Pliocene ocean chemistry and circulation based on a model developed for late Quaternary deep-water circulation in the Atlantic Ocean (Curry and Lohmann, 1983, 1985; Oppo and Fairbanks, 1987; Curry et al., 1988). Our principal measurements are the oxygen and carbon isotopic compositions of benthic foraminifers and the organic carbon accumulation in the sediments, all sensitive proxy indicators of ocean chemistry.

\section{Late Quaternary Model}

The response of the deep ocean to late Quaternary climate changes had dramatic consequences in the deep eastern Atlantic. Variations in benthic foraminiferal $\delta^{13} \mathrm{C}$ composition exceeded $1.0 \%$ and sedimentary organic carbon percentages varied from $<0.3 \%$ to $>1.5 \%$. Changes in isotopic chemistry and sediment lithology were systematic, with lowest $\delta^{13} \mathrm{C}$

\footnotetext{
${ }^{1}$ Ruddiman, W., Sarnthein, M., et al., 1989. Proc. ODP, Sci, Results, 108: College Station, TX (Ocean Drilling Program).

${ }^{2}$ Department of Geology and Geophysics, Woods Hole Oceanographic Institution, Woods Hole, MA 02543.

${ }^{3}$ Department of Geological Sciences, Rutgers University, New Brunswick, NJ 08903, and Lamont-Doherty Geological Observatory, Palisades, NY 10964.
}

values and highest organic carbon percentages occurring during maxima in Northern Hemisphere glaciation.

These chemical and lithological changes result from changes in the chemistry of deep water in the eastern basin. During glacial maxima,the production rate of North Atlantic Deep Water (NADW) decreased, which affected the chemistry of the deep water entering the eastern Atlantic across the Romanche Fracture Zone (Curry and Lohmann, 1983; Oppo and Fairbanks, 1987; Curry et al., 1988). About one-half of the glacial-interglacial amplitude of $\delta^{13} \mathrm{C}$ in the deep eastern Atlantic results from this effect.

Today, the deep water ventilating the eastern Atlantic is a well-oxygenated mixture of approximately $80 \%$ NADW and $20 \%$ Antarctic Bottom Water (AABW). During glacial maxima, reduced production of NADW (or its glacial equivalent) changed the location and depth of the mixing zone between NADW and AABW. As a result, a lower concentration of NADW entered the eastern Atlantic, lowering the dissolved oxygen concentration of this basin.

The very low benthic foraminiferal $\delta^{13} \mathrm{C}$ values in cores from below $3750 \mathrm{~m}$ (Fig. 1) suggest that minimum dissolvedoxygen concentrations $\left(\mathrm{O}_{2}\right)$ for the abyssal Atlantic occurred below this depth in the eastern basin. The steep bathymetric gradient in benthic foraminiferal $\delta^{13} \mathrm{C}$ (and presumably $\mathrm{O}_{2}$ ) in the eastern Atlantic (Curry and Lohmann, 1983, 1985) resulted in greater preservation of organic carbon as well as higher organic carbon concentrations in the deep sites of this region (Fig. 2).

The success of our reconstruction of late Quaternary deep circulation relies on the comparison of benthic foraminiferal chemistry and sediment lithology between shallow $(<3750 \mathrm{~m})$ and deep $(>3750 \mathrm{~m})$ locations. The vertical chemical gradients reflect the net effect of mixing between northern and southern sources of deep water and the changes in chemistry that occur from prolonged exposure of deep water to settling organic detritus. Today, the northern component of deep water is characterized by nutrient depletion and ${ }^{13} \mathrm{C}$ enrichment.

When northern-source water is mixed with southernsource deep water, $\delta^{13} \mathrm{C}$ values as well as dissolved oxygen and carbonate ion concentrations are lowered. The differences in $\delta^{13} \mathrm{C}$ between shallow and deep cores during glaciations 

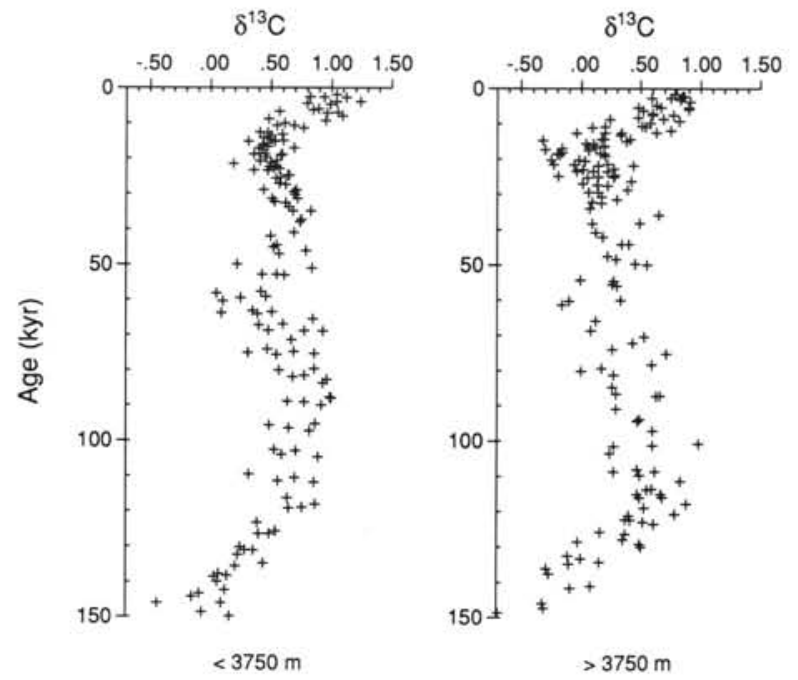

Figure 1. $\delta^{13} \mathrm{C}$ values for benthic foraminifers from late Quaternary sediments at the Sierra Leone Rise. The samples from above $3750 \mathrm{~m}$ have $\delta^{13} \mathrm{C}$ values that generally do not fall below $0 \%$ during glaciations (approximately 20,60 , and 140 k.y.). Below $3750 \mathrm{~m}, \delta^{13} \mathrm{C}$ values are $-0.2 \%$ to $-0.5 \%$, showing the effects of reduced production of NADW during glacial maxima. During interglacial isotopic stages, carbon isotopic values are similar above and below $3750 \mathrm{~m}$, showing that the eastern Atlantic is well ventilated with NADW at these times.
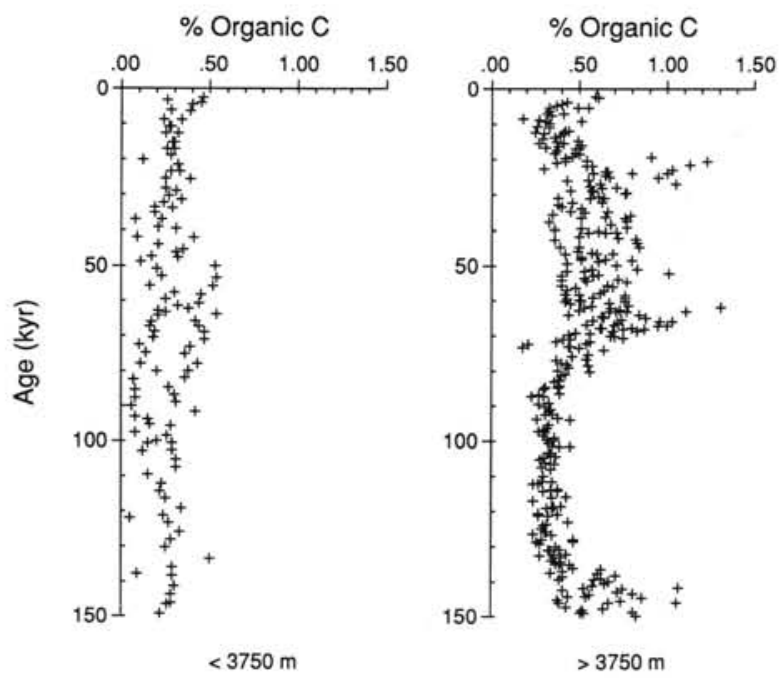

Figure 2. The bathymetric distribution of organic carbon in the late Quaternary sediments of the Sierra Leone Rise. Above $3750 \mathrm{~m}$, sedimentary organic carbon concentrations remain low throughout both interglacial and glacial intervals, while below $3750 \mathrm{~m}$ the concentrations increase to as much as $1.5 \%$ during glacial maxima. These elevated concentrations of organic carbon result from greater preservation in the deepest locations during glacial maxima when low $\delta^{13} \mathrm{C}$ (and $\mathrm{O}_{2}$ ) values occur in the deep water of the eastern Atlantic (cf. Fig. 1).

result from the increased contribution of southern-source deep water into the deepest eastern Atlantic. Shallow cores from the Sierra Leone Rise maintain $\delta^{13} \mathrm{C}$ values very similar to pure northern-component deep water even during glacial maxima (Oppo and Fairbanks, 1987), while deep cores vary in isotopic composition between nearly pure northern-component isotopic values during interglacial intervals to nearly pure southern component isotopic values during glacial intervals.
In this paper we follow a similar research strategy to reconstruct a history of ocean chemistry and sedimentation for the eastern Atlantic during the interval from 2.0 to 3.0 Ma. Site $665 \mathrm{~A}(4746 \mathrm{~m})$ was double cored with the APC in the eastern Atlantic south of the Sierra Leone Rise (Fig. 3), near the transect of cores used to develop our model for late Quaternary ocean circulation and chemistry (Fig. 3). It will serve as our best indicator of the conditions below the sill depth of the fracture zones that feed the eastern Atlantic.

Unfortunately, Leg 108 cores recovered above the sill depth had various problems that deemed them unsuitable for this analysis: Site 668 did not penetrate into the Pliocene; and Site 667 , although providing a good Tertiary record, did not produce an adequate paleomagnetic record, perhaps because of the extreme winnowing throughout most of the Pliocene section.

In order to provide an isotopic record of the northerncomponent end-member to compare with our equatorial record, we analyzed Cibicidoides spp. for the 2.0-3.0 Ma interval at Site 552, a record previously analyzed by Shackleton et al. (1984) using benthic foraminiferal isotopic samples of various species. By comparing these two records $\left(\delta^{13} \mathrm{C}\right.$ and $\delta^{18} \mathrm{O}$ values from both Holes $665 \mathrm{~A}$ and $552 \mathrm{~A}$ ), we will determine the amount of northern- or southern-component deep water that penetrated into the eastern Atlantic during the Pliocene.

\section{METHODS}

Isotopic analyses of benthic foraminifers followed standard procedures (Curry and Lohmann, 1982). The benthic taxon Cibicidoides spp. was picked from the $>250-\mu \mathrm{m}$ fraction of the sediment. Samples were spaced at $10-\mathrm{cm}$ intervals throughout Cores $108-665 \mathrm{~A}-6 \mathrm{H}$ and $-7 \mathrm{H}$. The samples were cleaned in an ultrasonic cleaner and roasted in a vacuum for $1 \mathrm{hr}$ prior to analysis. The calcium carbonate was reacted with $100 \% \mathrm{H}_{3} \mathrm{PO}_{4}$ at a constant temperature of $50^{\circ} \mathrm{C}$.

The evolved $\mathrm{CO}_{2}$ and water were then separated by a series of three distillations, and the purified $\mathrm{CO}_{2}$ was introduced into the inlet system of a VG Micromass $602 \mathrm{E}$ mass spectrometer at Woods Hole Oceanographic Institution. Measurements are referred to the PDB standard through intercalibration of our reference gas with NBS-20. Analytical precision for the analysis of isotopic standards was $\pm 0.06 \%$ for $\delta^{13} \mathrm{C}$ and $\pm 0.05 \%$ for $\delta^{18} \mathrm{O}$, while replicate analyses of unknown samples have poorer precision.

We analyzed organic carbon concentrations in the sediments according to procedures similar to those outlined in Curry and Lohmann (1985), with several modifications. After weighing the raw, dry samples, calcium carbonate was removed from the samples by acidification in 5-N phosphoric acid. The acidified samples were then filtered onto $0.7-\mu \mathrm{m}$ glass fiber filters, each of which were combusted at $800^{\circ} \mathrm{C}$. The evolved $\mathrm{CO}_{2}$ was measured in a Coulmetric $\mathrm{CO}_{2}$ Coulometer. Analytical precision for this measurement is $\pm 0.05 \%$.

\section{LITHOSTRATIGRAPHY}

\section{Site 665A}

Lithostratigraphy provides detailed correlations between holes at Site 665 (Fig. 4). Holes 665A and 665B were offset cored at this site in order to provide a continuous record of sediment without the interruption caused by coring disturbance. We have correlated the alternating dark (organiccarbon-rich) and light (organic-carbon-poor) layers in these holes to determine the amount of sediment lost between cores during drilling. Our correlation is anchored by the Gauss/ Matuyama boundary (G/M;2.47 Ma) within each core, and we have correlated above and below that level by matching various characteristic sequences of dark- and light-colored sediment layers.

On the basis of this correlation, we believe that approximately $70 \mathrm{~cm}$ of sediment is missing between Cores 108- 


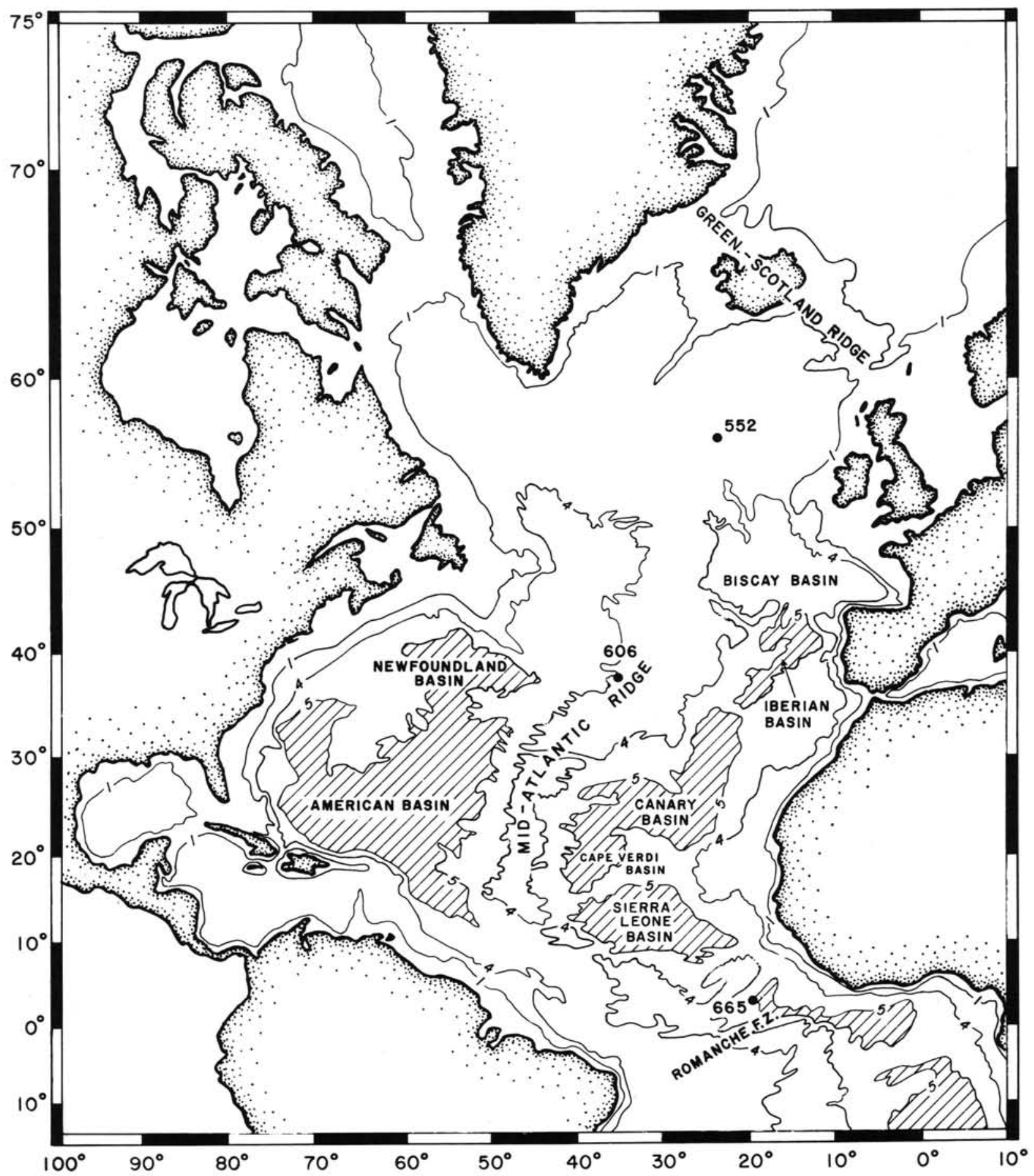

Figure 3. Location map showing the positions of Sites 665, 606, and 552.

$665 \mathrm{~A}-6 \mathrm{H}$ and $-7 \mathrm{H}$, while $1.6 \mathrm{~m}$ of sediment is missing between Cores $108-665 \mathrm{~B}-6 \mathrm{H}$ and $-7 \mathrm{H}$. The ages of samples at Hole $665 \mathrm{~A}$ have been determined by linear interpolation between the stratigraphic levels listed in Table 1. In the following discussions, we have adjusted the chronology of Core 108$665 \mathrm{~A}-7 \mathrm{H}$ to accommodate the missing section. With a mean sedimentation rate of about $1.5 \mathrm{~cm} / \mathrm{k} . \mathrm{y}$., the correction to the ages of samples from Core 108-665A-7H amounts to about $50,000 \mathrm{yr}$. We compared the resulting chronology of isotopic records at Hole 665A (Table 2, Fig. 5) with the magnetostratigraphic age estimates at Hole 552A.

\section{Site 552A}

Previous work by Keigwin (1986) has shown that benthic foraminiferal $\delta^{18} \mathrm{O}$ values increased at Hole 606 prior to the enrichment noted at $2.4 \mathrm{Ma}$ at Hole 552A and that the Site 606 record lacks the sudden change in amplitude that characterizes the Hole 552A isotopic record. Like Keigwin's (1986) record, oxygen isotopic enrichments at Hole 665 A occurred before $2.4 \mathrm{Ma}$, within the interval from 2.5 to $2.7 \mathrm{Ma}$ (Fig. 5). Because of the discrepancies between Holes 665A and 606 and Hole $552 \mathrm{~A}$, we have reevaluated the stratigraphy and core 


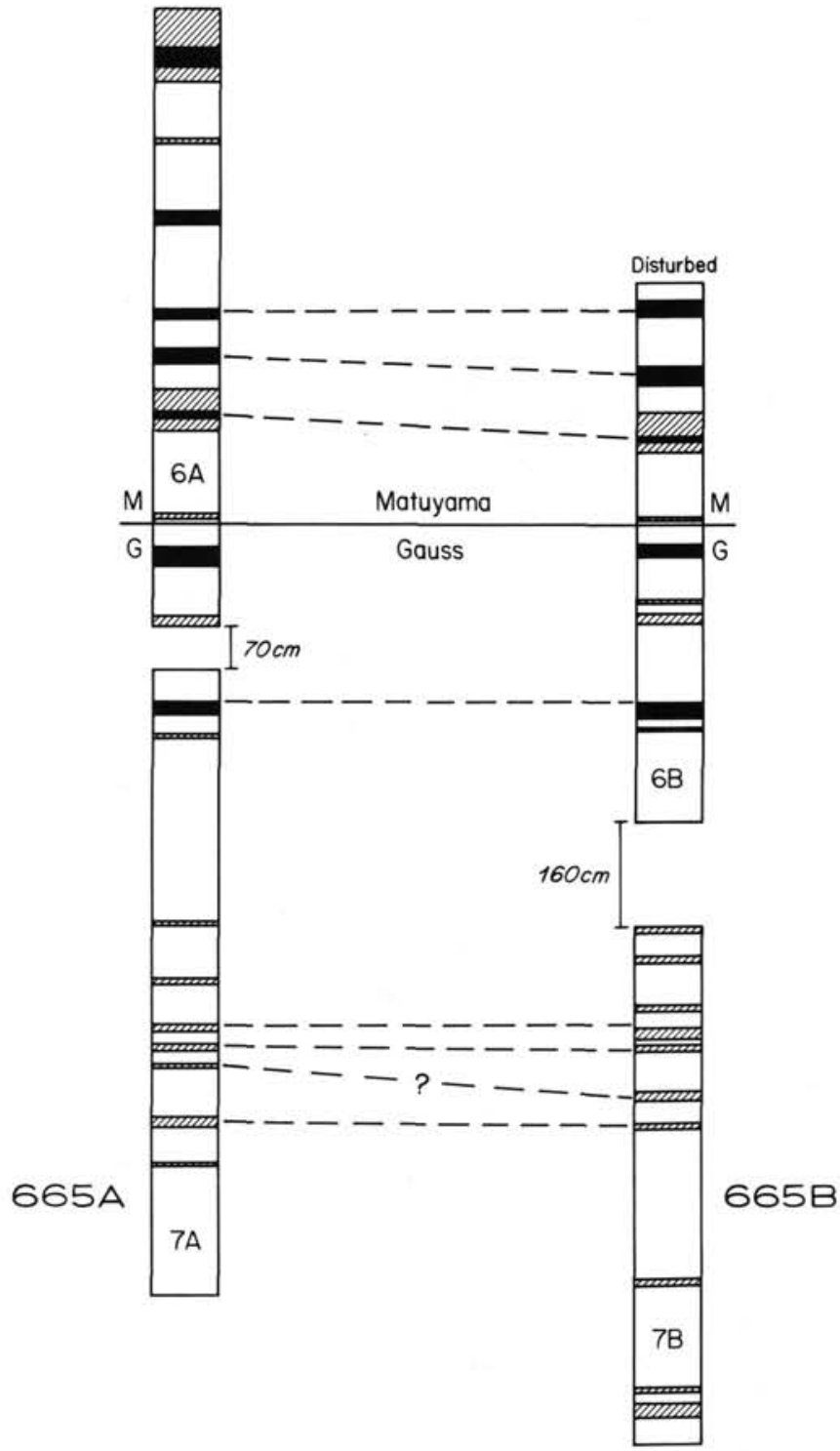

Figure 4. Lithostratigraphy of Cores $108-665 \mathrm{~A}-6 \mathrm{H}$ and $-7 \mathrm{H}$ and Cores $108-665 \mathrm{~B}-6 \mathrm{H}$ and $-7 \mathrm{H}$. We have correlated the holes by (1) paleomagnetic records and (2) sequences of alternating light (organic-carbonpoor) and dark (organic-carbon-rich) lithologies. On this basis, we believe that a total of $70-80 \mathrm{~cm}$ was lost between Cores $108-665 \mathrm{~A}-6 \mathrm{H}$ and $-7 \mathrm{H}$ and $160 \mathrm{~cm}$ was lost between Cores 108-665B-6H and $-7 \mathrm{H}$. We have adjusted the ages of our samples in Core $108-665 \mathrm{~A}-7 \mathrm{H}$ to reflect this sediment loss. Our correlation, based on magnetics and color, differs slightly from the correlation of Ruddiman, Sarnthein, et al. (1988). Their correlation, based on magnetic susceptibility, would enlarge the gap between Cores $108-665 \mathrm{~A}-6 \mathrm{H}$ and $-7 \mathrm{H}$.

recovery of Hole 552A to determine the continuity of sediment recovered in the middle Pliocene. Sedimentation rate estimates between important magnetic reversals at Hole 552A (Table 1) suggest that some sediment is missing.

The sedimentation rate at Hole 552A averaged about 13.7 $\mathrm{m} / \mathrm{m}$.y. between the top of the Olduvai Magnetosubchron (1.66 Ma) and the G/M boundary (2.47 Ma). Between the base of the Kaena Magnetosubchron (2.99 Ma) and the Gauss/ Gilbert boundary (3.40 Ma), the sedimentation rate averaged $21.5 \mathrm{~m} / \mathrm{m}$.y. The sedimentation rate was much lower, however, between the two important paleomagnetic boundaries in Cores $81-552 \mathrm{~A}-9 \mathrm{H}$ and $-10 \mathrm{H}$. The $\mathrm{G} / \mathrm{M}$ boundary occurs in
Table 1. Stratigraphic boundaries, ages, and sedimentation rates at Holes $665 \mathrm{~A}$ and $552 \mathrm{~A}$.

\begin{tabular}{lccl}
\hline $\begin{array}{c}\text { Depth } \\
\text { (mbsf) }\end{array}$ & $\begin{array}{c}\text { Age } \\
\text { (Ma) }\end{array}$ & $\begin{array}{c}\text { Sedimentation } \\
\text { rate } \\
(\mathrm{m} / \mathrm{m} . \mathrm{y} .)\end{array}$ & \multicolumn{1}{c}{ Comment } \\
\hline $\begin{array}{l}\text { Hole 665A: } \\
33.1\end{array}$ & 1.66 & 19.8 & $\begin{array}{l}\text { Top of Olduvai } \\
\text { Top of Gauss }\end{array}$ \\
49.1 & 2.47 & 15.5 & LO G. seminulina \\
57.3 & 3.00 & & Top of Olduvai \\
$\begin{array}{l}\text { Hole 552A: } \\
32.1\end{array}$ & 1.66 & 13.7 & Top of Gauss \\
43.2 & 2.47 & 8.8 & Base of Kaena \\
47.8 & 2.99 & 21.5 & Base of Gauss \\
\hline 56.6 & 3.40 & &
\end{tabular}

Note: $\mathrm{LO}=$ last occurrence.

Core $81-552 \mathrm{~A}-9 \mathrm{H}$ and the base of the Kaena occurs in Core $81-552 \mathrm{~A}-10 \mathrm{H}$; the sedimentation rate between the two intervals was only $8.8 \mathrm{~m} / \mathrm{m} . \mathrm{y}$.

One possible explanation for the low sedimentation rate between these two stratigraphic markers may be due to the loss of sediment between cores from drilling disturbances. We evaluated this possibility by estimating the age of the base of Core $81-552 \mathrm{~A}-9 \mathrm{H}$ and the top of Core $81-552 \mathrm{~A}-10 \mathrm{H}$ using the various sedimentation rates in Table 1 . Using the sedimentation rate for the interval between the top of the Olduvai and the $\mathrm{G} / \mathrm{M}$ boundary and extrapolating it below to the base of Core $81-552 \mathrm{~A}-9 \mathrm{H}$, we predict an age for the $9 / 10$ core break of $2.53 \mathrm{Ma}$

For the age of the top of Core $81-552 \mathrm{~A}-10 \mathrm{H}$, we have two estimates. Using the sedimentation rate between the base of the Kaena and the Gauss/Gilbert boundary $(21.5 \mathrm{~m} / \mathrm{m} . \mathrm{y}$.), we calculated an extrapolated age for the top of Core 81-552A$10 \mathrm{H}$ of approximately $2.81 \mathrm{Ma}$. Thus, if our calculations are correct, as much as $300,000 \mathrm{yr}$ of sediment are missing between Cores $81-552 \mathrm{~A}-9 \mathrm{H}$ and $-10 \mathrm{H}$. Another more conservative estimate of the age of the top of Core $81-552 \mathrm{~A}-10 \mathrm{H}$ can be obtained by extrapolating the sedimentation rate of 13.7 $\mathrm{m} / \mathrm{m}$.y. (the rate between the Olduvai and $\mathrm{G} / \mathrm{M}$ boundary) upward from the base of the Kaena Magnetosubchron. In this scenario the age of the top of Core $81-552 \mathrm{~A}-10 \mathrm{H}$ is approximately $2.71 \mathrm{Ma}$, and the hiatus between Cores $81-552 \mathrm{~A}-9 \mathrm{H}$ and $-10 \mathrm{H}$ would be about $180,000 \mathrm{yr}$.

Large sedimentation rate changes are likely to have occurred during this interval of climatic change, so extrapolations such as these should be performed with great reluctance. However, at those ODP and DSDP sites where offset hydraulic piston coring (HPC) was performed, we know that sediments are frequently missing between cores (as in Holes 665A and $665 \mathrm{~B}$ shown in Fig. 4). In fact, it is unlikely that continuous core recovery can be achieved without offset coring. Therefore, we believe that our calculations are reasonable, and we conclude that the equivalent of at least $180,000 \mathrm{yr}$ of sediment are missing from between Cores $81-552 \mathrm{~A}-9 \mathrm{H}$ and $-10 \mathrm{H}$. We have adjusted the chronology of Hole 552A accordingly (Table 2, Fig. 6).

\section{DATA}

\section{Stable Isotope}

Our Hole 552A isotopic data compare well with the records of Shackleton et al. (1984) and Shackleton and Hall (1984). 
Table 2. Isotopic data for Holes $665 \mathrm{~A}$ and 552A.

\begin{tabular}{|c|c|c|c|}
\hline $\begin{array}{l}\text { Depth } \\
\text { (mbsf) }\end{array}$ & $\begin{array}{l}\text { Age } \\
\text { (Ma) }\end{array}$ & $\begin{array}{c}\delta^{18} \mathrm{O} \\
(\mathrm{PDB})\end{array}$ & $\begin{array}{c}\delta^{13} \mathrm{C} \\
(\mathrm{PDB})\end{array}$ \\
\hline \multicolumn{4}{|c|}{$108-665 \mathrm{~A}-6 \mathrm{H}:$} \\
\hline 41.06 & 2.063 & 2.33 & 0.33 \\
\hline 41.38 & 2.079 & 2.44 & 0.15 \\
\hline 41.46 & 2.083 & 1.80 & -0.18 \\
\hline 41.56 & 2.088 & 2.41 & -0.73 \\
\hline 41.66 & 2.093 & 2.61 & -0.72 \\
\hline 41.85 & 2.103 & 2.93 & 0.94 \\
\hline 41.94 & 2.108 & 2.94 & -1.02 \\
\hline 42.04 & 2.113 & 2.88 & -0.66 \\
\hline 42.14 & 2.118 & 2.85 & -0.90 \\
\hline 42.24 & 2.123 & 1.71 & -0.38 \\
\hline 42.34 & 2.128 & 2.85 & -0.21 \\
\hline 42.43 & 2.132 & 1.73 & 0.46 \\
\hline 42.53 & 2.137 & 2.19 & 0.64 \\
\hline 42.63 & 2.142 & 1.59 & 0.16 \\
\hline 42.73 & 2.148 & 1.96 & 0.56 \\
\hline 42.83 & 2.153 & 2.14 & 0.20 \\
\hline 42.93 & 2.158 & 2.16 & 0.64 \\
\hline 43.07 & 2.165 & 2.22 & 0.27 \\
\hline 43.13 & 2.168 & 2.33 & 0.27 \\
\hline 43.23 & 2.173 & 2.93 & 0.37 \\
\hline 43.43 & 2.183 & 2.41 & 0.29 \\
\hline 43.53 & 2.188 & 2.85 & -0.27 \\
\hline 43.64 & 2.194 & 2.68 & 0.06 \\
\hline 43.73 & 2.198 & 2.42 & -0.10 \\
\hline 43.83 & 2.203 & 2.89 & -0.11 \\
\hline 43.93 & 2.208 & 2.77 & -0.06 \\
\hline 44.03 & 2.213 & 2.81 & -0.17 \\
\hline 44.23 & 2.223 & 2.94 & -0.48 \\
\hline 44.38 & 2.231 & 2.66 & -0.80 \\
\hline 44.43 & 2.234 & 2.44 & -0.50 \\
\hline 44.50 & 2.237 & 2.47 & -0.50 \\
\hline 44.73 & 2.249 & 2.24 & 0.63 \\
\hline 44.83 & 2.254 & 2.27 & -0.06 \\
\hline 44.93 & 2.259 & 2.44 & 0.80 \\
\hline 45.03 & 2.264 & 2.33 & -0.12 \\
\hline 45.14 & 2.270 & 2.39 & -0.36 \\
\hline 45.23 & 2.274 & 2.95 & -0.18 \\
\hline 45.33 & 2.279 & 2.83 & -0.21 \\
\hline 45.43 & 2.284 & 2.74 & -0.77 \\
\hline 45.53 & 2.289 & 2.25 & -0.37 \\
\hline 45.63 & 2.294 & 2.12 & -0.46 \\
\hline 45.73 & 2.299 & 2.28 & 0.23 \\
\hline 45.83 & 2.304 & 2.77 & -0.39 \\
\hline 45.93 & 2.310 & 2.55 & -0.60 \\
\hline 46.00 & 2.313 & 2.68 & -0.91 \\
\hline 46.10 & 2.318 & 2.21 & -0.42 \\
\hline 46.23 & 2.325 & 1.90 & 0.00 \\
\hline 46.33 & 2.330 & 2.24 & -0.41 \\
\hline 46.43 & 2.335 & 2.94 & -0.23 \\
\hline 46.53 & 2.340 & 3.11 & -0.71 \\
\hline 46.58 & 2.342 & 3.19 & -0.53 \\
\hline 46.67 & 2.347 & 2.91 & -0.87 \\
\hline 46.77 & 2.352 & 2.53 & -0.66 \\
\hline 46.87 & 2.357 & 2.09 & 0.16 \\
\hline 46.95 & 2.361 & 2.72 & 0.10 \\
\hline 47.05 & 2.366 & 2.67 & -0.76 \\
\hline 47.15 & 2.371 & 3.00 & -0.45 \\
\hline 47.35 & 2.381 & 3.28 & -0.57 \\
\hline 47.45 & 2.386 & 3.01 & -0.69 \\
\hline 47.56 & 2.392 & 2.53 & -0.98 \\
\hline 47.75 & 2.402 & 2.33 & -0.26 \\
\hline 47.85 & 2.407 & 2.37 & 0.27 \\
\hline 47.95 & 2.412 & 1.61 & 0.33 \\
\hline 48.05 & 2.417 & 2.26 & 0.20 \\
\hline 48.15 & 2.422 & 2.22 & 0.27 \\
\hline 48.25 & 2.427 & 2.02 & -0.36 \\
\hline 48.43 & 2.436 & 2.50 & 0.51 \\
\hline 48.63 & 2.446 & 1.53 & 0.34 \\
\hline 49.67 & 2.507 & 2.94 & -0.56 \\
\hline 49.77 & 2.513 & 2.51 & -0.30 \\
\hline 49.87 & 2.520 & 2.26 & 0.22 \\
\hline 49.93 & 2.524 & 2.32 & 0.36 \\
\hline 50.03 & 2.530 & 2.16 & 0.57 \\
\hline
\end{tabular}

Table 2 (continued).

\begin{tabular}{|c|c|c|c|}
\hline $\begin{array}{l}\text { Depth } \\
\text { (mbsf) }\end{array}$ & $\begin{array}{l}\text { Age } \\
\text { (Ma) }\end{array}$ & $\begin{array}{c}\delta^{18} \mathrm{O} \\
(\mathrm{PDB})\end{array}$ & $\begin{array}{c}\delta^{13} \mathrm{C} \\
(\mathrm{PDB})\end{array}$ \\
\hline 50.13 & 2.537 & 2.29 & 0.06 \\
\hline 50.23 & 2.543 & 2.21 & -0.03 \\
\hline 50.33 & 2.550 & 2.47 & -0.08 \\
\hline 50.43 & 2.556 & 2.59 & -0.10 \\
\hline 50.50 & 2.560 & 2.75 & -0.23 \\
\hline 50.57 & 2.565 & 2.74 & -0.20 \\
\hline \multicolumn{4}{|c|}{ 108-665A-7H: } \\
\hline 50.56 & 2.613 & 2.68 & -0.48 \\
\hline 50.66 & 2.619 & 2.67 & 0.09 \\
\hline 50.74 & 2.624 & 2.67 & -0.41 \\
\hline 50.86 & 2.631 & 2.70 & -0.89 \\
\hline 50.96 & 2.636 & 3.00 & -0.88 \\
\hline 51.07 & 2.643 & 2.86 & -0.49 \\
\hline 51.16 & 2.648 & 2.53 & -0.50 \\
\hline 51.26 & 2.654 & 2.19 & -0.44 \\
\hline 51.36 & 2.659 & 2.00 & -0.13 \\
\hline 51.56 & 2.671 & 1.90 & -0.04 \\
\hline 51.93 & 2.692 & 2.22 & -0.47 \\
\hline 52.03 & 2.698 & 2.31 & 0.03 \\
\hline 52.13 & 2.703 & 2.29 & 0.09 \\
\hline 52.23 & 2.709 & 2.02 & 0.25 \\
\hline 52.33 & 2.715 & 2.34 & 0.46 \\
\hline 52.43 & 2.721 & 1.90 & 0.18 \\
\hline 52.50 & 2.725 & 2.29 & 0.55 \\
\hline 52.63 & 2.732 & 2.11 & 0.09 \\
\hline 52.73 & 2.738 & 2.45 & -0.27 \\
\hline 52.83 & 2.744 & 2.70 & 0.13 \\
\hline 52.93 & 2.749 & 1.81 & 0.06 \\
\hline 53.03 & 2.755 & 1.74 & 0.68 \\
\hline 53.13 & 2.761 & 2.00 & 0.62 \\
\hline 53.23 & 2.767 & 2.21 & 0.63 \\
\hline 53.33 & 2.772 & 2.71 & 0.36 \\
\hline 53.43 & 2.778 & 1.99 & 0.57 \\
\hline 53.53 & 2.784 & 2.08 & -0.30 \\
\hline 53.63 & 2.789 & 2.31 & 0.47 \\
\hline 53.73 & 2.795 & 2.49 & 0.08 \\
\hline 53.83 & 2.801 & 2.64 & 0.05 \\
\hline 53.93 & 2.807 & 2.34 & 0.60 \\
\hline 54.00 & 2.811 & 2.42 & 0.32 \\
\hline 54.13 & 2.818 & 2.38 & 0.15 \\
\hline 54.23 & 2.824 & 2.43 & 0.41 \\
\hline 54.33 & 2.830 & 2.34 & 0.10 \\
\hline 54.43 & 2.835 & 2.67 & -0.25 \\
\hline 54.63 & 2.847 & 2.21 & 0.07 \\
\hline 54.73 & 2.853 & 2.43 & 0.64 \\
\hline 54.93 & 2.864 & 2.04 & -0.06 \\
\hline 55.03 & 2.870 & 2.32 & 0.49 \\
\hline 55.13 & 2.876 & 1.84 & 0.31 \\
\hline 55.23 & 2.881 & 2.14 & 0.35 \\
\hline 55.33 & 2.887 & 2.64 & 0.58 \\
\hline 55.43 & 2.893 & 2.55 & 0.48 \\
\hline 55.50 & 2.897 & 2.52 & 0.23 \\
\hline 55.63 & 2.904 & 2.55 & 0.23 \\
\hline 55.74 & 2.911 & 2.75 & 0.13 \\
\hline 55.83 & 2.916 & 2.44 & 0.06 \\
\hline 55.93 & 2.921 & 2.11 & 0.40 \\
\hline 56.03 & 2.927 & 2.37 & 0.36 \\
\hline 56.13 & 2.933 & 2.35 & 0.14 \\
\hline 56.23 & 2.939 & 2.12 & 0.61 \\
\hline 56.33 & 2.944 & 2.20 & 0.45 \\
\hline 56.53 & 2.956 & 2.08 & 0.58 \\
\hline 56.63 & 2.962 & 2.21 & 0.75 \\
\hline 56.73 & 2.967 & 1.66 & 0.55 \\
\hline 56.83 & 2.973 & 1.54 & 0.24 \\
\hline 56.93 & 2.979 & 1.87 & 0.53 \\
\hline 57.00 & 2.983 & 1.87 & 0.06 \\
\hline 57.13 & 2.990 & 1.75 & -0.11 \\
\hline 57.21 & 2.995 & 2.60 & -0.06 \\
\hline 57.33 & 3.002 & 1.87 & 0.51 \\
\hline 57.44 & 3.008 & 1.57 & 0.41 \\
\hline 57.53 & 3.013 & 1.93 & -0.10 \\
\hline 57.64 & 3.020 & 1.97 & 0.56 \\
\hline 57.83 & 3.030 & 1.96 & 0.81 \\
\hline 57.93 & 3.036 & 1.73 & 0.44 \\
\hline
\end{tabular}


Table 2 (continued).

\begin{tabular}{|c|c|c|c|}
\hline $\begin{array}{l}\text { Depth } \\
\text { (mbsf) }\end{array}$ & $\begin{array}{l}\text { Age } \\
\text { (Ma) }\end{array}$ & $\begin{array}{c}\delta^{18} \mathrm{O} \\
(\mathrm{PDB})\end{array}$ & $\begin{array}{c}\delta^{13} \mathrm{C} \\
(\mathrm{PDB})\end{array}$ \\
\hline \multicolumn{4}{|l|}{ 81-552A: } \\
\hline 37.06 & 2.022 & 3.57 & 0.52 \\
\hline 37.14 & 2.228 & 3.52 & 0.40 \\
\hline 37.22 & 2.034 & 3.30 & 0.71 \\
\hline 37.35 & 2.043 & 3.31 & 0.56 \\
\hline 37.47 & 2.052 & 2.84 & 0.92 \\
\hline 37.55 & 2.058 & 3.08 & 0.79 \\
\hline 37.64 & 2.064 & 3.03 & 0.86 \\
\hline 37.82 & 2.077 & 3.07 & 0.89 \\
\hline 37.91 & 2.084 & 2.63 & 0.70 \\
\hline 38.04 & 2.093 & 3.59 & 0.58 \\
\hline 38.16 & 2.102 & 3.64 & 0.56 \\
\hline 38.24 & 2.108 & 2.99 & 0.25 \\
\hline 38.37 & 2.118 & 2.97 & 0.87 \\
\hline 38.48 & 2.126 & 2.97 & 0.95 \\
\hline 38.51 & 2.128 & 2.95 & 0.83 \\
\hline 38.61 & 2.135 & 3.06 & 0.78 \\
\hline 38.71 & 2.142 & 2.77 & 0.83 \\
\hline 38.79 & 2.148 & 3.00 & 0.92 \\
\hline 39.06 & 2.168 & 2.80 & 1.04 \\
\hline 39.14 & 2.174 & 2.98 & 1.28 \\
\hline 39.24 & 2.181 & 2.97 & 0.94 \\
\hline 39.35 & 2.189 & 2.93 & 1.17 \\
\hline 39.46 & 2.197 & 3.24 & 0.96 \\
\hline 39.56 & 2.204 & 3.31 & 1.03 \\
\hline 39.67 & 2.212 & 3.03 & 0.75 \\
\hline 39.74 & 2.218 & 2.74 & 0.98 \\
\hline 39.87 & 2.227 & 2.81 & 0.96 \\
\hline 39.95 & 2.233 & 2.40 & 0.33 \\
\hline 40.06 & 2.241 & 3.11 & 0.59 \\
\hline 40.17 & 2.249 & 2.43 & 0.54 \\
\hline 40.26 & 2.255 & 2.71 & 0.48 \\
\hline 40.35 & 2.262 & 2.75 & 0.81 \\
\hline 40.46 & 2.270 & 2.63 & 1.02 \\
\hline 40.57 & 2.278 & 2.74 & 0.94 \\
\hline 40.65 & 2.284 & 2.89 & 0.73 \\
\hline 40.75 & 2.291 & 3.37 & 0.47 \\
\hline 40.85 & 2.299 & 3.45 & 0.54 \\
\hline 40.95 & 2.306 & 3.54 & 0.61 \\
\hline 41.08 & 2.315 & 2.82 & 0.81 \\
\hline 41.14 & 2.320 & 2.47 & 0.76 \\
\hline 41.25 & 2.328 & 2.76 & 0.64 \\
\hline 41.34 & 2.334 & 3.28 & 0.24 \\
\hline 41.46 & 2.343 & 2.73 & 0.77 \\
\hline 41.55 & 2.350 & 2.58 & 0.57 \\
\hline 41.64 & 2.356 & 2.77 & 0.61 \\
\hline 41.74 & 2.363 & 2.74 & 0.55 \\
\hline 41.84 & 2.371 & 3.49 & 0.52 \\
\hline 41.94 & 2.378 & 3.62 & 0.26 \\
\hline 42.06 & 2.387 & 3.43 & 0.33 \\
\hline 42.16 & 2.394 & 2.89 & 0.55 \\
\hline 42.26 & 2.401 & 2.51 & 0.75 \\
\hline 42.36 & 2.409 & 2.69 & 1.02 \\
\hline 42.44 & 2.415 & 2.70 & 0.91 \\
\hline 42.56 & 2.423 & 2.96 & 1.14 \\
\hline 42.65 & 2.430 & 2.71 & 1.14 \\
\hline 42.76 & 2.438 & 2.87 & 1.09 \\
\hline 42.85 & 2.444 & 2.76 & 0.88 \\
\hline 42.95 & 2.452 & 2.90 & 0.69 \\
\hline 43.05 & 2.459 & 2.74 & 0.72 \\
\hline 43.14 & 2.466 & 2.71 & 0.92 \\
\hline 43.27 & 2.475 & 2.84 & 0.98 \\
\hline 43.35 & 2.481 & 2.42 & 0.62 \\
\hline 43.44 & 2.488 & 2.94 & 0.87 \\
\hline 43.56 & 2.497 & 2.92 & 0.84 \\
\hline 43.66 & 2.504 & 2.78 & 0.87 \\
\hline 43.76 & 2.512 & 2.73 & 1.13 \\
\hline 44.06 & 2.714 & 2.67 & 0.99 \\
\hline 44.15 & 2.720 & 2.46 & 1.25 \\
\hline 44.26 & 2.780 & 2.67 & 1.15 \\
\hline 44.35 & 2.735 & 2.63 & 0.88 \\
\hline 44.45 & 2.743 & 2.37 & 1.17 \\
\hline 44.57 & 2.751 & 2.65 & 1.10 \\
\hline 44.64 & 2.757 & 2.79 & 0.97 \\
\hline 44.75 & 2.765 & 2.42 & 0.62 \\
\hline 44.85 & 2.772 & 2.64 & 1.05 \\
\hline 44.94 & 2.779 & 2.89 & 1.06 \\
\hline
\end{tabular}

Table 2 (continued).

\begin{tabular}{cccc}
\hline $\begin{array}{c}\text { Depth } \\
\text { (mbsf) }\end{array}$ & $\begin{array}{c}\text { Age } \\
\text { (Ma) }\end{array}$ & $\begin{array}{c}\delta^{18} \mathrm{O} \\
(\mathrm{PDB})\end{array}$ & $\begin{array}{c}\delta^{13} \mathrm{C} \\
(\mathrm{PDB})\end{array}$ \\
\hline 45.06 & 2.788 & 2.70 & 1.30 \\
45.14 & 2.793 & 2.82 & 1.03 \\
45.25 & 2.802 & 2.87 & 1.21 \\
45.35 & 2.809 & 2.90 & 0.89 \\
45.45 & 2.816 & 2.77 & 1.24 \\
45.55 & 2.824 & 2.34 & 0.64 \\
45.65 & 2.831 & 2.58 & 0.98 \\
45.75 & 2.839 & 2.47 & 1.28 \\
45.85 & 2.846 & 2.78 & 0.92 \\
45.93 & 2.852 & 2.75 & 0.79 \\
46.05 & 2.861 & 2.10 & 0.86 \\
46.15 & 2.868 & 2.33 & 0.97 \\
46.25 & 2.875 & 2.27 & 0.96 \\
46.35 & 2.883 & 2.63 & 1.04 \\
46.45 & 2.890 & 2.64 & 1.09 \\
46.55 & 2.898 & 2.66 & 1.13 \\
46.65 & 2.905 & 2.66 & 1.15 \\
46.87 & 2.921 & 2.71 & 1.04 \\
46.96 & 2.928 & 2.62 & 1.01 \\
\hline
\end{tabular}

Note: Isotopic data are presented with respect to the PDB standard without correction for isotopic disequilibrium. Cibicidoides species were analyzed in each sample.
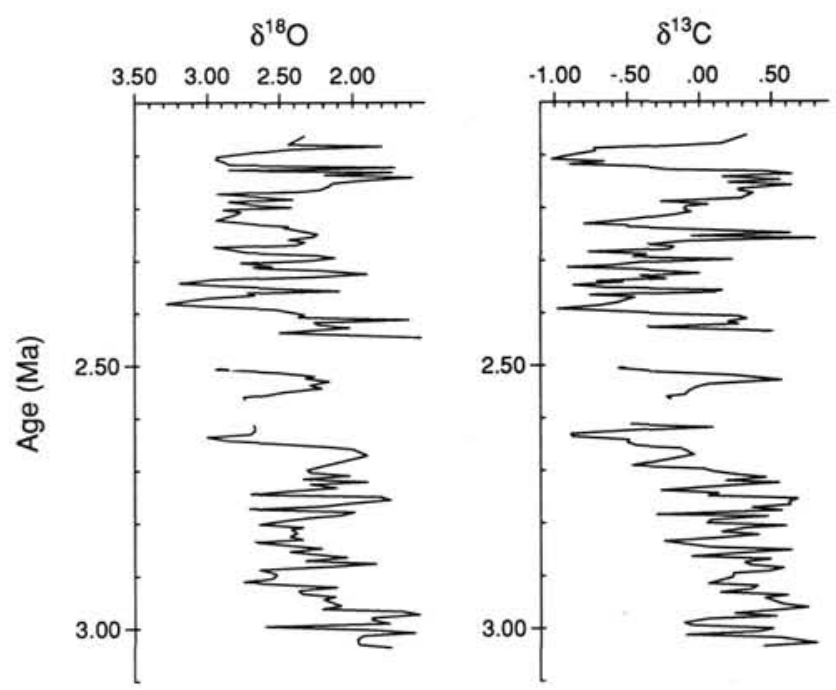

Figure 5. Oxygen and carbon isotopic records for benthic foraminifers in Hole $665 \mathrm{~A}$. Cibicidoides spp. $(>250 \mu \mathrm{m})$ were analyzed at $10-\mathrm{cm}$ spacing throughout Cores $108-665 \mathrm{~A}-6 \mathrm{H}$ and $-7 \mathrm{H}$. The oxygen isotopic record exhibits the important enrichments associated with Pliocene glaciation at 2.4 Ma and later (Shackleton et al., 1984). It also shows significant enrichments at 2.5 Ma and earlier (see also Keigwin, 1986). The carbon isotopic record exhibits low values throughout the entire interval, with the values approaching those typical of Pliocene isotopic records in the Pacific Ocean (Shackleton and Hall, 1984; E. Sikes, pers. comm., 1987).

Our Cibicidoides isotopic data agrees with their Cibicidoides data (Fig. 6), whereas the overall trends of the complete data sets show similar patterns. The only important difference between the record of Shackleton et al. (1984) and our record occurs at about $2.4 \mathrm{Ma}$. The magnitude of the $\delta^{18} \mathrm{O}$ increase at $2.4 \mathrm{Ma}$ observed by Shackleton et al. (1984) equaled glacial increases observed in late Quaternary isotopic records $(1.8 \%)$.

If the enrichment was due mostly to ice-volume increase (as it is during the late Quaternary), the ice-volume increase at 


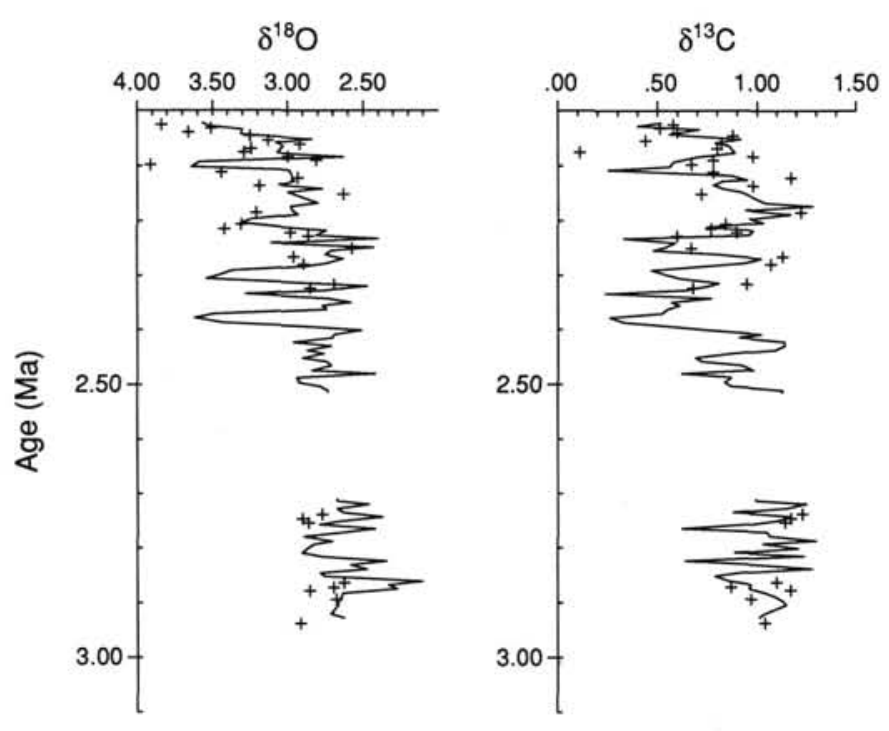

Figure 6. Oxygen and carbon isotopic records for benthic foraminifers at Hole $552 \mathrm{~A}$ in the northern North Atlantic (line $=$ Cibicidoides isotopic data, this study; crosses = Cibicidoides isotopic data of Shackleton et al., 1984). The oxygen isotopic changes observed in this record are similar to those observed by Shackleton et al. (1984), except that the increase in $\delta^{18} \mathrm{O}$ observed at $2.4 \mathrm{Ma}$ is not as large for Cibicidoides spp. as for G. subglobosa. Our observations are similar to those made by Keigwin (1986) in the record of Hole 606.

2.4 Ma was as large as any in the Pleistocene. However, our $\delta^{18} \mathrm{O}$ record for Hole $552 \mathrm{~A}$, produced only from an analysis of Cibicidoides spp., does not record the same full glacial isotopic enrichment. The 2.4-Ma $\delta^{18} \mathrm{O}$ increase in Cibicidoides spp. at Hole 552A was similar in magnitude to the enrichment observed by Keigwin (1986) at Hole 606 . The maximum $\delta^{18} \mathrm{O}$ values observed in Holes 606 and 552A at this time were about $3.6 \%$ PDB, which is $0.5 \%-0.7 \%$ lower than maximum values observed in late Quaternary Cibicidoides in northern Atlantic Ocean cores (Curry et al., 1988).

These differences in $\delta^{18} \mathrm{O}$ enrichment can be caused by at least three factors: (1) changes in species' vital effect, (2) bioturbation of species with different abundance variations, and (3) regional variations in the temperature structure of the oceans. Since coexisting benthic foraminifers have different oxygen and carbon isotopic compositions (Shackleton, 1977; Woodruff et al., 1980; Belanger et al., 1981; Graham et al., 1981), it has been customary to add correction factors to the raw isotopic data to produce a composite record of "equilibrium" $\delta^{18} \mathrm{O}$ and $\delta^{13} \mathrm{C}$ values. This procedure was followed by Shackleton et al. (1984) when they produced the record for Hole 552A. In particular, the benthic taxa used to produce the record near the 2.4-Ma event were Globocassidulina subglobosa and Uvigerina peregrina.

This procedure requires the assumption that all benthic species maintained constant differences in isotopic composition. Although this is a reasonable assumption, there are examples when the differences are not constant. For instance, Keigwin (1986) demonstrated that coexisting G. subglobosa and Cibicidoides spp. did not produce similar isotopic enrichments at $2.4 \mathrm{Ma}$ at Hole 606 . In low sedimentation rate cores, such differences may be caused by the bioturbation of two taxa with abundance variations that are periodic and out of phase (Mix and Fairbanks, 1985); in cores with high sedimentation rates (like Hole 606), this problem is minimized.

Consequently, we believe that the extreme enrichment in ${ }^{18} \mathrm{O}$ at $2.4 \mathrm{Ma}$ in the original Hole $552 \mathrm{~A}$ isotopic record may result from inconstant isotopic disequilibrium. Although regional variations in oceanic temperature structure may explain the differences between Holes 552A and 665A, Holes 606 and 552A are close enough (i.e., geographically) to rule out this hypothesis. Thus, the data for Cibicidoides spp. suggest that the glacial enrichment was only about two-thirds of the magnitude of full late Quaternary glacial enrichments.

The carbon isotopic record for Hole 552A agrees well with the values presented by Shackleton et al. (1984) for Cibicidoides spp. (Fig. 6) and for intervals where other species' isotopic data were corrected to Cibicidoides values. Throughout the entire record, the $\delta^{13} \mathrm{C}$ values exceeded $0.2 \%$, with most of the values falling between $0.5 \%$ and $1.3 \%$. After the major $\delta^{18} \mathrm{O}$ event at $2.4 \mathrm{Ma}$, the amplitude of $\delta^{13} \mathrm{C}$ variations increased to nearly $1.0 \%$, mostly due to lower $\delta^{13} \mathrm{C}$ values during enriched ${ }^{18} \mathrm{O}$ intervals. Thus, the Pliocene $\delta^{13} \mathrm{C}$ and $\delta^{18} \mathrm{O}$ records exhibited the same negative covariance observed in the late Quaternary.

The isotopic records for Hole $665 \mathrm{~A}$ exhibit many similarities to those of Hole 552A, but there are differences that place important constraints on past ocean chemistry, circulation, and climatic history. The oxygen isotopic values for Hole $665 \mathrm{~A}$ were generally lower than those observed at Hole 552A, and throughout much of the Pliocene they exhibited higher amplitude variations (Fig. 7). Like the Hole 552A record, the most enriched ${ }^{18} \mathrm{O}$ values occurred just after the $\mathrm{G} / \mathrm{M}$ boundary at $2.4 \mathrm{Ma}$. The most enriched values were about $3.3 \%$, or $0.3 \%$ lower than coeval Cibicidoides spp. values at Holes 606 and $552 \mathrm{~A}$.

In late Quaternary sediments near Hole 665A, interglacial $\delta^{18} \mathrm{O}$ values averaged about $2.5 \%$ and glacial $\delta^{18} \mathrm{O}$ values averaged about $4.1 \%$ (Curry and Lohmann, 1983), so the most enriched values at $2.4 \mathrm{Ma}$ were about $50 \%-60 \%$ of full glacial values. As observed at Hole 606 (Keigwin, 1986), oxygen isotopic enrichments occurred at Hole $665 \mathrm{~A}$ before 2.4 Ma.

A well-defined enrichment occurred in Hole $665 \mathrm{~A}$ at about $2.6 \mathrm{Ma}$ and another less well-defined enrichment occurred at about $2.5 \mathrm{Ma}$. Prior to $2.7 \mathrm{Ma}, \delta^{18} \mathrm{O}$ variations were of a lower amplitude and $\delta^{18} \mathrm{O}$ values did not exceeding $3.0 \%$. Minima in $\delta^{18} \mathrm{O}$ were much lower at Hole $665 \mathrm{~A}$ than at Hole $552 \mathrm{~A}$ throughout the interval from 2.0 to $3.0 \mathrm{Ma}$. At Hole 552A, the lowest $\delta^{18} \mathrm{O}$ values always exceeded $2.0 \%$, while at Hole $665 \mathrm{~A}$ minimum values approached $1.5 \%$ oo. Consequently, the amplitude of $\delta^{18} \mathrm{O}$ variation was greater at Hole $665 \mathrm{~A}$ throughout most of this interval.

Carbon isotopic compositions of benthic foraminifers at Hole $665 \mathrm{~A}$ were also generally lower than at Hole $552 \mathrm{~A}$ throughout this 1-m.y. record (Fig. 7), and this observation is true for glacial and interglacial climatic extremes. During the late Quaternary, the carbon isotopic composition of benthic foraminifers in the deep eastern Atlantic equaled the carbon isotopic composition of northern North Atlantic benthic foraminifers during interglacial climates because of the dominance of NADW in this basin (Curry and Lohmann, 1983).

Carbon isotope values were about $1.0 \%$ lower during late Quaternary glacial maxima when the influence of northern component deep water was diminished and the influence of southern source water prevailed in this basin (Oppo and Fairbanks, 1987; Curry et al., 1988). In contrast, Pliocene $\delta^{13} \mathrm{C}$ values in the deep eastern Atlantic were always lower than northern North Atlantic $\delta^{13} \mathrm{C}$ values. During Pliocene interglaciations, the difference in $\delta^{13} \mathrm{C}$ (Hole $665 \mathrm{~A}-$ Hole 552A) was about $0.5 \%$, but during glaciations (like $2.4 \mathrm{Ma}$ ) the difference approached $1.5 \%$. These larger amplitude changes in 


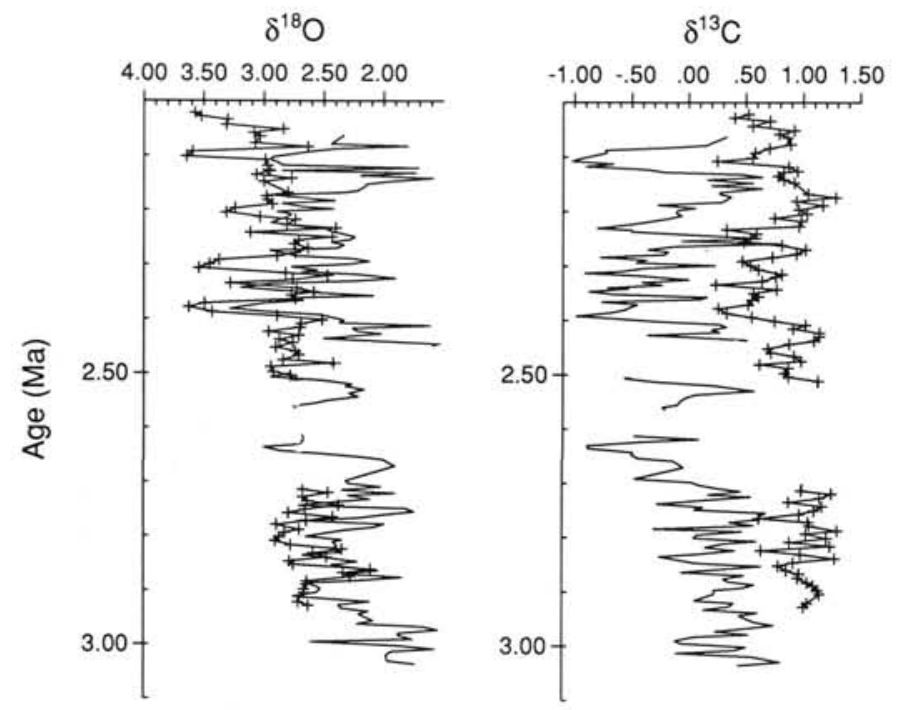

Figure 7. The oxygen and carbon isotopic records of Hole 665 A (line) and 552A (crosses) plotted on a common time scale. Note that the $\delta^{18} \mathrm{O}$ values of Hole $665 \mathrm{~A}$ are generally lower throughout the entire Pliocene record, and that the enrichments in $\delta^{18} \mathrm{O}$ begin before 2.4 Ma. The $\delta^{18} \mathrm{O}$ values at Hole $665 \mathrm{~A}$ in the eastern Atlantic are generally lower and more like the values observed in the Pacific Ocean at this time (average $=$ approximately $-0.5 \%$, corrected to Cibicidoides; Shackleton and Hall, 1984). The $\delta^{13} \mathrm{C}$ values at Hole 665 A are lower than those at Hole 552A throughout this interval. Lower $\delta^{13} \mathrm{C}$ values are also present in the Pacific Ocean in the middle Pliocene (Shackleton and Hall, 1984; E. Sikes, pers. comm., 1987), and we believe that the low values in the eastern Atlantic must represent the penetration of southern-source deep water further north into the Atlantic Ocean at this time.

$\delta^{13} \mathrm{C}$ suggest that the deep-water mixture in the deep eastern Atlantic oscillated between northern and southern components, which had a larger difference in $\delta^{13} \mathrm{C}$.

Lower $\delta^{13} \mathrm{C}$ values during the Pliocene imply that dissolved oxygen concentrations in the eastern Atlantic were also lower. The direct conversion of $\delta^{13} \mathrm{C}$ variations into $\mathrm{O}_{2}$ gradients may not be reliable because we are not able to constrain the preformed $\mathrm{O}_{2}$ and $\delta^{13} \mathrm{C}$ values for deep-water masses (Mix and Fairbanks, 1985; Curry and Lohmann, 1985). If we assume that the northern- and southern-source water masses had similar preformed values, however, the $\delta^{13} \mathrm{C}$ differences between Holes $665 \mathrm{~A}$ and $552 \mathrm{~A}$ were equivalent to $\mathrm{O}_{2}$ gradients of about $70 \mu \mathrm{mol} / \mathrm{kg}$ during Pliocene interglaciations and more than $200 \mu \mathrm{mol} / \mathrm{kg}$ during Pliocene glaciations. Today, the dissolved oxygen concentration in the eastern Atlantic is $220-250 \mu \mathrm{mol} / \mathrm{kg}$ (Bainbridge, 1981). Thus, the gradients in $\delta^{13} \mathrm{C}$ observed during Pliocene glaciations suggest that dissolved oxygen concentrations may have been very low in the deep eastern Atlantic.

\section{Organic Carbon}

The concentration of organic carbon in the sediments at Hole $665 \mathrm{~A}$ varied from $\sim 0 \%$ to $>0.8 \%$ by weight throughout the interval from 2.0 to $3.0 \mathrm{Ma}$ (Fig. 8). The amplitude of organic carbon variations increased significantly after $2.4 \mathrm{Ma}$ at this location. The highest organic carbon concentrations occurred during intervals of low $\delta^{13} \mathrm{C}$ in the deep eastern Atlantic (Pliocene glaciations), which suggests that variations in the dissolved oxygen concentration of the deep water may have contributed to the preservation of organic carbon in the

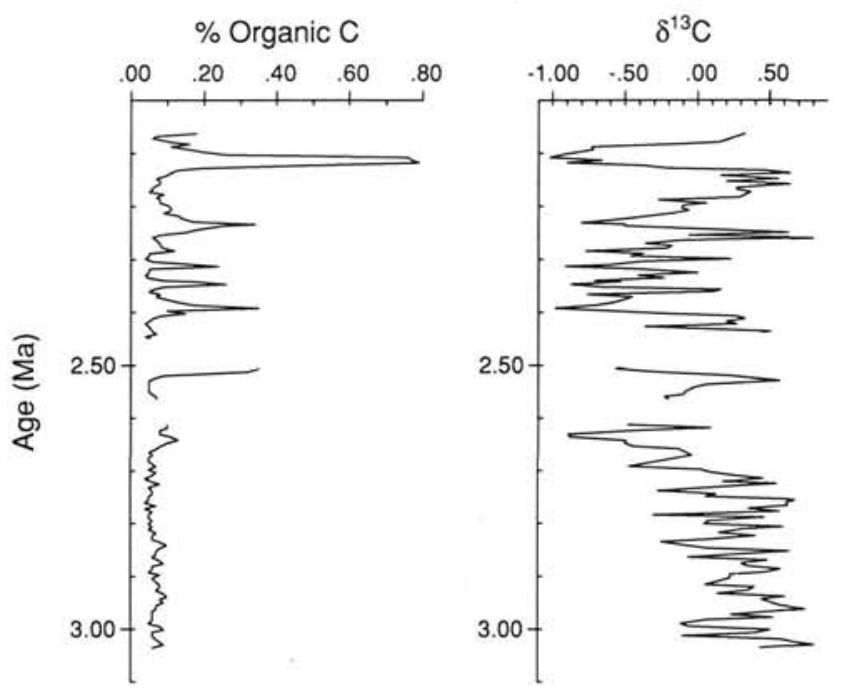

Figure 8. Organic carbon concentration and $\delta^{13} \mathrm{C}$ variations at Hole $665 \mathrm{~A}$. Organic carbon concentrations increased after $2.4 \mathrm{Ma}$, and maxima correlate with minima in benthic foraminiferal $\delta^{13} \mathrm{C}$ and maxima in benthic foraminiferal $\delta^{18} \mathrm{O}$. These records suggest that low $\mathrm{O}_{2}$ occurred in the equatorial Atlantic during Pliocene glaciations and contributed to an increased preservation of organic carbon in the sediments.

sediments. (As yet we have no constraint on the effects of changes in organic carbon productivity on these sediment concentrations.)

Overall, Pliocene organic carbon concentrations are lower than concentrations observed in the late Quaternary, even though the patterns of alternating dark- and light-colored sequences appear similar. It is likely that some of the organic carbon has decayed since burial. In a core near to Hole $665 \mathrm{~A}$, Müller et al. (1982) observed an exponential decay of organic carbon with a half-life on the order of $1 \mathrm{~m}$.y. If their observations are correct, then only about one-fourth of the original organic carbon concentration remains in the Pliocene sediments of Hole 665A.

\section{DISCUSSION}

\section{Pliocene Deep-Water Circulation}

Low benthic foraminiferal $\delta^{13} \mathrm{C}$ values in the eastern Atlantic suggest that northern component deep water, with its characteristic enriched ${ }^{13} \mathrm{C}$ values, had less influence on the eastern equatorial Atlantic during most of the middle Pliocene. The $\delta^{13} \mathrm{C}$ value of water in the deep eastern Atlantic never equaled the northern-component $\delta^{13} \mathrm{C}$ value, as it did during late Quaternary interglacial intervals. The deep water present in the eastern Atlantic during Pliocene glacial intervals had isotopic values nearly equal to those found in the Pacific Ocean at that time (V28-179: Shackleton and Hall, 1984; Hole 503B: E. Sikes, pers. comm., 1987). The geometry of deep-water masses in the Pliocene Atlantic more closely resembled the deep-water geometry of the glacial intervals of the late Quaternary Atlantic Ocean. A complete time series of Cibicidoides isotopic values from the Pliocene Pacific Ocean is needed to confirm this observation, however.

During the late Quaternary, low $\delta^{13} \mathrm{C}$ deep water with a southern origin penetrated into the equatorial region of the 
Atlantic and altered the isotopic composition of the deep water entering the deep eastern Atlantic through low-latitude fracture zones. This change in deep-water flow was made possible because of decreased production of northern-component deep water (i.e., NADW), which allowed a greater northward penetration of this southern water mass. Thus, $\delta^{13} \mathrm{C}$ values in the eastern Atlantic during late Quaternary glaciations were nearly identical to the values observed throughout much of the Pacific Ocean (Oppo and Fairbanks, 1987; Curry et al., 1988). A similar spatial distribution of $\delta^{13} \mathrm{C}$ occurred during all glacial and most interglacial intervals throughout the Pliocene from 3.0 to $2.0 \mathrm{Ma}$.

The Atlantic-Pacific difference in $\delta^{13} \mathrm{C}$ was greater during the Pliocene than observed today (Shackleton and Hall, 1984), suggesting that a relatively nutrient-depleted deep-water mass was present at Hole 552A throughout this entire interval (Shackleton and Hall, 1984). During late Quaternary glaciations, the difference between the Atlantic and the Pacific was slightly reduced over its interglacial value of $1.0 \%$ ond was much less than the nearly $1.5 \%$ differences observed during some Pliocene glacial intervals.

The strong gradient in $\delta^{13} \mathrm{C}$ between the northern North Atlantic and the Pacific suggests, therefore, that production of deep water in the North Atlantic was an active process during the Pliocene. Its limited southward penetration, however, suggests that either the production rate of this water mass was lower than today or the production rate of the southern-source water mass was much greater.

\section{Pliocene Ocean Chemistry}

A larger $\delta^{13} \mathrm{C}$ difference between the North Atlantic and the Pacific Ocean (Shackleton and Hall, 1984) implies that there were large gradients in the distribution of nutrients and $\mathrm{O}_{2}$ in the Pliocene deep ocean. There are at least two possible reasons for this pattern. First, the increased gradient in $\delta^{13} \mathrm{C}$ may have resulted from greater nutrient depletion of the NADW at its site of formation. Today, NADW is formed with a preformed nutrient concentration $\left(\mathrm{PO}_{4}\right)$ of about $1 \mu \mathrm{mol} / \mathrm{kg}$. It is a mixture of many components, some very depleted in nutrients (e.g., North Atlantic surface water) and others less so (e.g., Mediterranean outflow, Labrador Sea deep water). By changing the mixing ratio between these components, a more nutrient-depleted, ${ }^{13} \mathrm{C}$-enriched deep water could have been formed in the Pliocene northern North Atlantic. Alternatively, this northern-component deep water could have formed much like today, but in an ocean with a mean nutrient concentration greater than today's.

Boyle (1986) has shown that increasing the nutrient concentration of the world's oceans not only increases the surface-water to deep-water $\delta^{13} \mathrm{C}$ gradient, as shown by Broecker (1982), but also steepens the $\delta^{13} \mathrm{C}$ gradient between the Atlantic and Pacific oceans because more nutrients are removed from the deep-water sources and recycled into the deep waters of the Pacific. The result is a larger difference in $\delta^{13} \mathrm{C}$, $\mathrm{PO}_{4}$, and $\mathrm{O}_{2}$ between the oceans.

Although we have no evidence that increased nutrient concentration occurred at this time, there are two tests that could confirm the hypothesis: (1) $\mathrm{Cd} / \mathrm{Ca}$ measurements on benthic foraminifers should record elevated levels (Boyle and Keigwin, 1982), and (2) the surface-water to deep-water $\delta^{13} \mathrm{C}$ difference should be increased (Broecker, 1982) if the mean nutrient concentration of the oceans was greater during the Pliocene.

\section{Pliocene Climate}

Our measurements of benthic foraminiferal $\delta^{18} \mathrm{O}$ in the Pliocene sections of Holes $552 \mathrm{~A}$ and $665 \mathrm{~A}$ suggest that the glacial climate at this time was probably only about one-half to two-thirds as severe as late Quaternary glaciations. At present, we do not understand why the isotopic differences between $G$. subglobosa and Cibicidoides spp. appear to have changed during the Pliocene (Keigwin, 1986). Unfortunately, the problem of inconstant isotopic disequilibrium cannot be solved with this type of data; it will require more extensive studies of the living organisms in the modern ocean (Corliss, 1985).

The isotopic record at Hole $665 \mathrm{~A}$ suggests that at least two $\delta^{18} \mathrm{O}$ enrichments occurred prior to the increase at $2.4 \mathrm{Ma}$. We cannot determine if these enrichments occurred because of deep-water cooling or because of ice-volume increases. Our observations of early ${ }^{18} \mathrm{O}$ enrichments are very similar to those of Keigwin (1986), however. We believe that these earlier ${ }^{18} \mathrm{O}$ enrichments were not observed at Hole 552A because some of the section was lost during coring. Unfortunately, we cannot determine precisely how much section was lost at Hole 552A because offset coring was not performed at this site. On the basis of the other $\delta^{18} \mathrm{O}$ records (Holes 606 and $665 \mathrm{~A}$ ), it seems likely that Northern Hemisphere glaciations occurred during the Pliocene prior to $2.4 \mathrm{Ma}$.

\section{CONCLUSIONS}

The isotopic records of Hole 665A provide a record of the changes in deep-water chemistry and the earth's climate for the Pliocene interval from 3.0 to 2.0 Ma. When compared with the changes in oxygen and carbon isotopic composition of benthic foraminifers at Hole 552A, the changes at Hole 665A reflect temporal variations in the extent of deep-water production in the North Atlantic and the northward penetration of deep water from the Southern Ocean. Throughout the entire 1-m.y. record presented here, penetration of northern-source deep water into the eastern North Atlantic was less than during late Quaternary glaciations.

The carbon isotopic composition of benthic foraminifers in the eastern Atlantic was similar to Pacific benthic foraminifers during Pliocene glaciations and often fell between North Atlantic and Pacific values during Pliocene interglaciations. Thus, mixing of deep water in the deep eastern Atlantic followed the late Quaternary model; that is, during glaciations a greater proportion of southern-source deep water entered the eastern basins. The very high amplitude changes in $\delta^{13} \mathrm{C}$ during the Pliocene suggest that the difference in $\delta^{13} \mathrm{C}$ between northern- and southern-source endmember compositions was greater than observed in the late Quaternary.

The oxygen isotopic enrichments observed at Hole 665A and our Cibicidoides spp. data from Hole 552A show that the increase in $\delta^{18} \mathrm{O}$ at $2.4 \mathrm{Ma}$ was only one-half to two-thirds as large as observed in late Quaternary glaciations, lower than originally suggested by Shackleton et al. (1984). As yet, we have no way to determine which record more accurately reflects the intensity of glaciation in the Pliocene.

Pliocene $\delta^{18} \mathrm{O}$ enrichments occurred at Hole $665 \mathrm{~A}$ before 2.4 Ma, at times which apparently correlate with the enrichments observed by Keigwin (1986). On the basis of sedimentation rate arguments, we believe that a coring gap exists in Hole $552 \mathrm{~A}$, caused by incomplete recovery between Cores $81-552 \mathrm{~A}-9 \mathrm{H}$ and $-10 \mathrm{H}$. Coring gaps of similar thickness can be observed in Holes 665 A and 665B.

\section{ACKNOWLEDGMENTS}

We would like to thank L. Keigwin, D. Oppo, W. Ruddiman, and an anonymous reviewer for their helpful criticisms of the first draft of this paper. This research was supported by grant OCE85-11014 (W. B. Curry) and grants OCE85-21690 and OCE88-17563 (K. G. 
Miller) from the National Science Foundation and a grant from the United States Science Advisory Committee (USSAC). This is Woods Hole Oceanographic Institution Contribution No. 6930 and LamontDoherty Geological Observatory Contribution No. 4475.

\section{REFERENCES}

Bainbridge, A. E, 1981. GEOSECS Atlantic Expedition: Hydrographic Data (Vol. 1): Washington (U. S. Govt. Printing Office).

Belanger, P. E., Curry, W. B., and Matthews, R. K., 1981. Core-top evaluation of benthic foraminiferal isotopic ratios for paleo-oceanographic interpretations. Palaeogeogr., Palaeoclimatol., Paleoecol., 33:205-220.

Boyle, E. A., 1986. Paired carbon isotope and cadmium data from benthic foraminifera: implications for changes in oceanic phosphorus, oceanic circulation, and atmospheric carbon dioxide. Geochim. Cosmochim. Acta, 50:265-276.

Boyle, E. A., and Keigwin, L. D., 1982. Deep circulation of the North Atlantic over the last 200,000 years: geochemical evidence. Science, 218:784-787.

Broecker, W. S., 1982. Glacial to interglacial changes in ocean chemistry. Prog. Oceanogr., 11:151-197.

Corliss, B. H., 1985. Microhabitats of benthic foraminifera within deep-sea sediments. Nature, 314:435-438.

Curry, W. B., Duplessy, J. C., Labeyrie, L., and Shackleton, N. J., 1988. Changes in the distribution of $\delta^{13} \mathrm{C}$ of deep water $\mathrm{ECO}_{2}$ between the last glaciation and the Holocene. Paleoceanography, $3: 317-341$.

Curry, W. B., and Lohmann, G. P., 1982. Carbon isotopic changes in benthic foraminifera from the western South Atlantic: reconstruction of glacial abyssal circulation patterns. Quat. Res. 18:218-235. 1983. Reduced advection into Atlantic Ocean deep eastern basins during last glaciation maximum. Nature, 306:577-580. 1985. Carbon deposition rates and deep water residence time in the equatorial Atlantic Ocean throughout the last 160,000 years. In Sundquist, E. T., and Broecker, W. S. (Eds.), The Carbon Cycle and Atmospheric $\mathrm{CO}_{2}$ : Natural Variations Archean to Present: Washington (American Geophysical Union), 223-350.
Graham, D. W., Corliss, B. H., Bender, M. A., and Keigwin, L. D., Jr., 1981. Carbon and oxygen isotopic disequilibria of Recent deep-sea foraminifera. Mar. Micropaleontol., 6:483-497.

Keigwin, L. D., 1986. Pliocene stable-isotope record of Deep Sea Drilling Project Site 606: sequential events of ${ }^{18} \mathrm{O}$ enrichment beginning at 3.1 Ma. In Ruddiman, W. F., Kidd, R. B., Thomas, E., et al., Init. Repts. DSDP, 94, Pt. 2: Washington (U. S. Govt. Printing Office), 911-920.

Mix, A., and Fairbanks, R. G., 1985. North Atlantic surface-ocean control of Pleistocene deep-ocean circulation. Earth Planet. Sci. Lett., 73:231-243.

Müller, P. J., Erlenkeuser, H., and von Grafenstein, R., 1983. Glacial-interglacial cycles in oceanic productivity from organic carbon contents in eastern North Atlantic sediment cores. In Thiede, J., and Suess, E. (Eds.), Coastal Upwelling: Its Sediment Record (Pt. B): New York (Plenum Press), 365-398.

Oppo, D. W., and Fairbanks, R. G., 1987. Variability in the deep and intermediate water circulation of the Atlantic Ocean during the past 25,000 years: Northern Hemisphere modulation of the Southern Ocean. Earth Planet. Sci. Lett., 86:1-15.

Shackleton, N. J., 1977. Tropical rain forest history and the equatorial Pacific dissolution cycles. In Andersen, N. R., and Malahoff, A. (Eds.), Fate of Fossil Fuel $\mathrm{CO}_{2}$ in the Oceans: New York (Plenum Press), 401-427.

Shackleton, N. J., and Hall, M. A., 1984. Oxygen and carbon isotope stratigraphy of Deep Sea Drilling Project Hole 552A: Plio-Pleistocene glacial history. In Roberts, D. G., Schnitker, D., et al., Init. Repts. DSDP, 81: Washington (U. S. Govt. Printing Office), 599-609.

Shackleton, N. J., and the Leg 81 Shipboard Scientific Party, 1984. Oxygen isotope calibration of the onset of ice-rafting and history of glaciation in the North Atlantic Region. Nature, 307:620-623.

Woodruff, F., Savin, S. M., and Douglas, R. G., 1980. Biological fractionation of oxygen and carbon isotopes by Recent benthic foraminifera. Mar. Micropaleontol., 5:3-11.

Date of initial receipt: 5 July 1988

Date of acceptance: 6 December 1988

Ms 108B-134 